\title{
The impact of word of mouth and university reputation on student decision to study at univer- sity
}

\author{
Dedy Ansari Harahap ${ }^{a^{*}}$, Ratih Hurriyati ${ }^{b}$, Vanessa Gaffar ${ }^{c}$ and Dita Amanah
}

a,b,c,d Universitas Pendidikan Indonesia, Indonesia

${ }^{a}$ Universitas Islam Sumatera Utara, Indonesia

${ }^{d}$ Universitas Negeri Medan, Indonesia

CHRONIC L E A B T T R A C T

Article history:

Received: November 26, 2017

Received in revised format: January 31,2018

Accepted: April 7, 2018

Available online:

April 14, 2018

Keywords:

Word of Mouth

University Reputation

Student Decision

UISU

\begin{abstract}
This study aims to analyze the influence of word of mouth and university reputation on student decision to study at faculty of economics at the Universitas Islam Sumatera Utara (UISU), Indonesia. This research uses quantitative approach with explanatory research type. The sample size includes all 177 new university students of academic year 2015-2016 and processed statistically with multiple linier regression method. Results show that word of mouth does not positively influence on students' decision to study. Otherwise, university reputation partially had a positive and significant effect on students' decision to study. In addition, word of mouth and university reputation influence on students' decision to study. This shows that prospective students do not consider word-of-mouth good and bad information of the UISU, but rather consider the university's reputation in choosing a place to study. UISU should do more professionally in fulfilling facilities and infrastructure and improving the quality of lecturers. Tight competition requires universities to always build a good reputation through new breakthroughs that can be a mainstay and have a high selling value. UISU is required to be more professional by prioritizing user satisfaction.
\end{abstract}

(C) 2018 by the authors; licensee Growing Science, Canada

\section{Introduction}

Education is one of the priorities for most people and many people wish to achieve to some higher education. They are certainly faced with various options and issues such as choosing campus, study program, quality, cost, etc. Indrajit and Djokopranoto (2006) point out five dimensions of meaning colleges or institutions in the field of education, namely the dimension of knowledge (science and technology), the dimensions of education (higher education), the social dimension (community life), the dimensions of the corporation (educational unit and implementation) and ethical dimensions. Globalization according to Indrajit and Djokopranoto (2006) not only concerns and affects the economic field, but also it influences on almost on all elements of human life, so globalization also affects the colleges

* Corresponding author

E-mail address: dedyansariharahap@student.upi.edu (D.A. Harahap) 
sooner or later. The impact of globalization on education in Indonesia has a domestic dimension. Globalization provides positive opportunities and challenges for all universities, especially in quality improvement and competitiveness (Allam, 2018).

The decision of the students to continue their studies at the desired place of field of study plays an important role for their future success. If reality does not match to what is expected then the success will go under uncertainty. The act of choosing a university has many dimensions and impacts, which is part of a resolution effort as well as part of the decision-making process. The intense competition makes every university aware of a need to fully exploit its assets to maximize performance and to develop competitive advantage. One way to achieve this is to develop a college name so that it has a good reputation in the people's eyes and builds a trust.

Word of Mouth is an action that consumers provide information to other consumers about the characteristics of a product such as brand, product or service. Personal communication channels in the form of word of mouth can be an effective method of promotion. Satisfied customers will give chain messages to others (Enterprise, 2010). Marketing trends using word of mouth in campaigns rely on personal power to spread word of mouth (Enterprise, 2010). Word of mouth is a way of sharing ideas, beliefs and experiences with one another (Balter \& Butman, 2005). Higher education can be said a potential business today even now the reputation of a university becomes very important and it is the main capital for business developers in the field of education. Good reputation reflects the quality of the university. But this is not an easy thing for universities to develop in Indonesia because the increasingly intense competition with other universities. Alessandri et al. (2006) also Finch et al. (2013) found that the reputation of the university was crucial for new graduates looking for jobs. Therefore every university seeks to create a positive image and reputation in the face of competition with other universities. Universities should be more competitive in attracting students and providing opportunities for the best employment opportunities (Alessandri et al., 2006). Each university should be able to create competitive advantage to attract the best students and work in the best companies (Finch et al., 2013). Graduates from reputable universities will have an impact on the workplace and also affect their performance. Each student will feel that studying at a reputable university will show the level of success of getting the job he/she wants. This will create an impression for the company to the graduates and make graduates feel proud and worthy to be employed (Sultan \& Wong, 2012). UISU was established on January 7, 1951 with the strong struggle and determination of all UISU academic community and support from government, theologian and society. Currently UISU manages 9 faculties and 26 bachelor programs, 3 master programs and 1 doctoral program in Economics and Policy of UISU cooperation with UII Jogjakarta. The faculty and also the courses are: Law, Islam, Economics, English Literature, Teacher Training and Education, Social Sciences and Political Science, Agriculture, Medicine, Engineering and Postgraduate (www.uisu.ac.id). Faculty of Economics UISU was established by the UISU Foundation on 16 February 1957 which is the oldest Faculty of Economics of private universities in Sumatera.

Based on the previous description above, this study aims to know the influence of : 1) word of mouth on student decision to choose Faculty of Economics, UISU, 2) the university's reputation on the student's decision to choose Faculty of Economics, UISU, 3) word of mouth and university reputation to decision of student choose Faculty of Economics, UISU.

\section{Literature Review}

\subsection{Student Decision}

\subsubsection{Definition of Student Decision}

Kotler (2005) suggests decision-making is an individual activity that is directly involved in obtaining and using goods. Consumer decision is one part of consumer behavior. Swastha and Handoko (2008) argued that consumer behavior is an individual activity directly involved in obtaining and using goods and services included in the decision-making process. The decision chosen by students to continue their 
studies to college is a key to the continuity of the college cycle because students are an asset to every college. The decision taken is the selection of universities as a place to study that is broadly described in consumer behavior.

Cognitive and affective aspects are involved in consumer decisions including knowledge, understanding and beliefs acquired through memory and attention. Comprehensive processes interpret information on the surrounding environment (Peter \& Olson, 1999) and generally consumer decisions depend on a combination of experience, marketing and other information (Schiffman \& Kanuk, 2004). According to Schiffman and Kanuk (2007) purchasing decisions are the choice of two or more alternative purchasing decision choices, meaning that one can make decisions from several alternative choices and the decisions taken lead to how the process of decision-making. Assauri (2010) states that the purchase decision is a process that includes what will be purchased or not purchased. According to Kotler (2005), purchasing decisions are a problem-solving process consisting of analyzing needs and wants, searching information, valuing sources of selection on alternative purchases, purchasing decisions, and post purchase behavior. Consumer behavior will determine the decision making process in the purchase. Before deciding the purchase of goods or services, consumers will go through several stages. Consumer decision making process by Kotler (2005) are problem recognition, information search, validation of alternative, purchase decision, post purchase behavior.

A marketer should be able to evaluate the factors that influence consumer purchase decisions. Harahap (2015) states that the location, price and completeness of the products maintain a substantialimpact on consumer purchasing decisions. Every company should pay attention to the strategic place of business, competitive prices and completeness of the product to meet consumer needs. Understanding of the above purchasing decisions is assumed as a student decision to choose the place of study. It was concluded that the decision to vote was the attitude of the prospective student to a university to determine the choice of the intended university. Behavior of students for choosing a field of study in determining the university is to achieve students' wishes such as introduction to several universities, search for university information, evaluation of some university options, choose a university and behavior after choose a university.

\subsubsection{Indicator of student decision to choose university}

According to Kotler (2002) indicators of purchasing decisions include perceived needs, activities before buying, time-consuming behavior and post-purchase behavior. In this research, the students' decision to choose a university is measured using five indicators: 1) Introduction to several universities, 2) Search for university information, 3) evaluation of alternatives university options, 4) decision to choose university and 5) behavior after choosing university.

\subsection{Word of mouth}

\subsubsection{Definition of word of mouth}

Word of Mouth (WoM) is a message about products, services or companies in the form of comments about the product, friendliness, honesty, speed of service and others felt and experienced by someone then delivered to others. The message can be either positive or negative depending on what is felt. According to Hasan (Hasan, 2010) word of mouth is the action consumers provide some information to others and delivered again to other people or inter-personal about products or services. Sumardy et al., (2011) also confirmed the word of mouth is the action consumers provide information or the impression of a good and service to others. Word of Mouth is an unconscious and spontaneous special activity that cannot be controlled directly (Allsop et al., 2007). According Arndt (1967) word of mouth specifically as an oral communication from person to person where the recipient of information is not commercial to the brand, product or service delivered to him. Word of mouth is also called free adver- 
tising which can be interpreted as a form of information or ideas about goods or services that are identified without pay (Buttle, 1998). Customers who obtained the company through word of mouth, have more value in the long term compared with customers from other marketing channels (Villanueva et al., 2008).

According to Brown et al. (2005) word of mouth is informal communication between non-commercial person with others about the information of a product, brand and the company in the form of goods or services. It interpreted as an activity of providing information in marketing that indicates someone will tell others about his/her experience either positively or negatively when buying and consuming a product or service. According to Davidow (2003) word of mouth is a U-shaped relationship in which a person who is satisfied to consume a product provides positive information mouth to mouth and an unsatisfied person will give negative information or impression to others. According Sernovitz (2009) word of mouth divided into two types : 1) Organic WoM is the process of word of mouth happens naturally where everyone who feels happy and satisfied on a product will have the desire naturally provide spontaneous support. 2) Amplified WoM is the process of word of mouth appears intentionally by the company because it happens every marketer in the company do campaigns and promotions from the design to encourage the delivery process mouth to mouth to consumers. The way of delivering information or word of mouth strategy is strongly associated with the reference of the group so that it becomes the reference source for the consumer consisting of; Relations, friends, neighbors, associations and families. Consumers decide purchases usually consider impressions and information from reference groups rather than information from advertisers or salespeople. According to Hasan (2010) there are eight strategies to create word of mouth: 1) Provide experiences that exceed customer expectations, 2) Optimization of WOM strategy, 3) Rewards become a continuous commitment, 4) Reduce negative media, 5) Provide influencer opportunity to create and deliver services, 6) Encourage emotional bonding, 7) Create messages that are easy to transfer to others and 8) Reviewing customer placement roles.

Based on the opinion of experts above it can be concluded that word of mouth is a conversational activity or waffle that can affect and influenced by consumers to buy a product or service. WoM can be used as a reference or recommendation for consumers because consumers are usually difficult to assess a product and service if no experience of a particular product. Word of mouth has an important role in shaping loyal attitudes and behavior in the science of consumer behavior.

\subsubsection{Indicators of Word of Mouth}

According to Babin et al. (2005) WoM indicator is the willingness of the consumer to talk positively about the quality of service company to others, recommendation of a company service to others, impulse to friend or relation to make purchases of certain goods or services.

\subsection{University Reputation}

\subsubsection{Definition of University Reputation}

Reputation is an assessment of the attitudes, emotions, finances, social and culture of an organization with various people in general (Heath \& Vasquez, 2001). According to Fombrun and Shanley (1990) reputation is a description of the assessment and attitude of various individuals concerned about the state of a company. According to Tkalac and Ver (2007) and Melewar et al. (2005) company's reputation is understood as an image and identity function established by firms based on organizational culture

such as company history, activities, values and behavior. The image is shaped from the thinking of external stakeholders to the organization based on (Balmer \& Greyser, 2002; Hatch \& Schultz, 1997; Melewar et al., 2005).

Based on signal theory, the benefits of reputation is an informative signal about the behavior and performance of the organization that will increase public confidence in the product, service and investor 
confidence in the performance of a company (Smith et al., 2010; Walker, 2010). There are 3 (three) elements of reputation that is; Brand reputation, reputation of the organization and reputation of stakeholders. The company's reputation is the end of a chain that begins with the company's image, in which the company's image is derived from its corporate identity or brand derived from the characteristics created by an organization (www.studio.co.uk). Post and Griffin (1997) state that reputation is a combination of opinion, perception, and behavior of the stakeholders of an organization. In line with Eberl and Schwaiger (2005) reputation is a kind of behavioral construction that functions in the public mind. Reputation is also considered as a collection of facts experienced and perceived from products through social processes and not an impression in the minds of people personally (Helm, 2007). Reputation is an invisible vital asset and if managed suitably will be able to increase the organization's ability to sell its products and services, attract investors, hire talented workers and anticipate the influence of the surrounding political situation. A good reputation brings many benefits and benefits otherwise a bad reputation can bring down an organization (Heath \& Vasquez, 2001). Four things that affect the reputation of an organization that is; Credibility, reliability, responsibility and trustworthiness. The four influence each other and together form the organization's reputation (Fombrun \& Shanley, 1990).

According to Jung and Seock (2016), the marketing manager needs to improve the company's negative reputation. Companies must reduce negative influences with positive reputations. If the customer has a negative perception of the company or product then it can lead to a decrease in sales and corporate profits (Gray \& Balmer, 1998). Therefore it can be said that reputation is a combination of opinion, perception and behavior of each individual or organization in providing assessment at all times about the performance of the organization or company based on the emotional, financial, social and cultural linkage between the organization and the interested parties. Based on the illustration above it can be concluded that the reputation of the university becomes very important to be considered by prospective students in determining the right attitude to continue study in college according to the needs and desires. The university reputation can be measured by the popularity of that university (brand identity), the total number of applicants and the ratio of the amount received to the number of applicants (Indrajit \& Djokopranoto, 2006). The university's reputation is also described as the overall representation held by various universities over the years (Alessandri et al., 2006). By applying the general principle of a reputation proposed by (Alessandri et al., 2006; Bromley, 2006; Caruana, 2002; Fombrun \& Shanley, 1990; Gotsi \& Wilson, 2001; Grunig et al., 1995) we can say that a university's reputation could be established based on the experience of college graduates in direct or indirect interaction through information from the university.

\subsubsection{Indicator of University Reputation}

Sontaite (2011) presents ten indicators in measuring corporate reputation in higher education institutions: emotional appeal, behavior, study, citizenship and social responsibility, leadership, performance, workplace, competition, career, and innovation. The most important factor for higher education are innovation, behavior, performance and studies. The least important indicator of corporate reputation for higher education are attractive leaders, environmental responsibility, value for money and admiration.

\section{The proposed study}

\section{Conceptual Frame}

Fig. 1 shows the structure of the proposed study of this paper and three hypotheses are derived.

\section{Hypothesis}

H1 : Word of mouth influencing student decision to choose study in faculty economics UISU.

H2 : University's reputation influencing the student's decision.

H3 : Word of mouth and university reputation influencing the student's decision. 


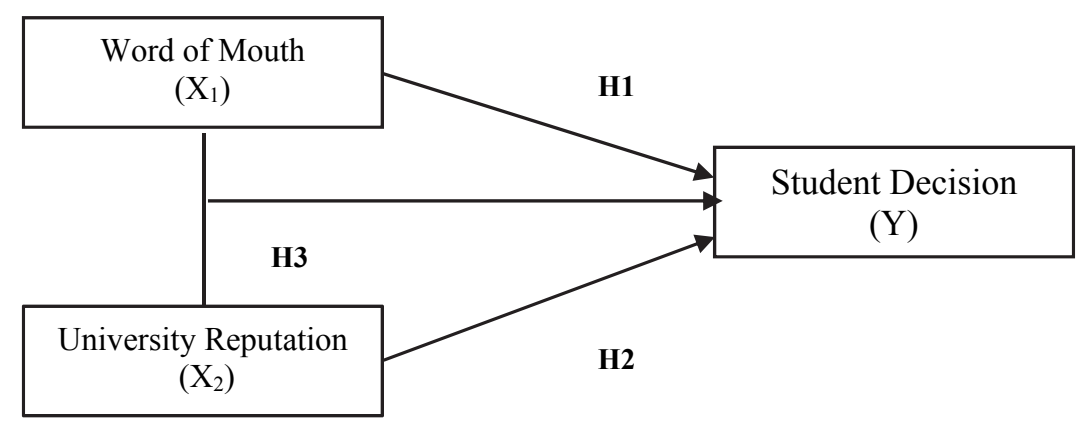

Fig. 1. Conceptual Frame

\subsection{Methodology}

This study was executed at faculty of economics of UISU located at Jalan Sisingamangaraja Teladan Barat Medan. The sample are all 177 students of academic year of 2015-2016 and random sampling method is used in this survey and the necessary data were collected using questionnaire. This type of study is a quantitative approach with explanatory research type. Data analysis technique is multiple regression analysis with the SPSS program.

\section{Results and Findings}

The multiple regression analysis result is $\mathrm{Y}=4.960+0.189 \mathrm{X} 1+0.826 \mathrm{X} 2+\mathrm{e}$. The constant value of 4.960 means that when there is no variable $X$ then the student decision is 4.960 (assuming another factor is constant). The $\mathrm{X}_{1}$ is 0.189 , means every change of word of mouth will influence the decision of student (assumption of other factors constant) and $\mathrm{X}_{2}$ is 0.826 , which also means every change of one unit of university reputation will influence student decision with (the condition of another constant factor).

\subsection{The Influence of Word of Mouth on Student Decision}

The result of statistical t-test is equal to 1.377 and t-table is 1,654 at $95 \%$ significance level with alpha $5 \%$ which is $1.377<1.654$ and $\mathrm{Ho}_{1}$ is accepted and $\mathrm{Ha}_{1}$ is rejected. Hypothesis rejected means positive word of mouth does not significantly influence the decision of students to study.

\section{The Influence of University Reputation on Student Decision}

The result of statistical test using t test obtained t-value is equal to 8.204 which is again greater than 1.654. Obviously $\mathrm{Ho}_{2}$ is rejected and $\mathrm{Ha}_{2}$ is accepted. Hypothesis accepted means positive university reputation significantly influences on the decision of students to study. F test results obtained F-value is equal to 123.370 which is greater than the F-table value of 3.05. Because F-value $>$ F-table this means Ho is rejected and Ha is accepted, It can be concluded that word of mouth and university reputation positive significantly influence the decision of student to study.

$\mathrm{R}^{2}$ is 0.586 , means $58.60 \%$ of students' decisions can be explained by word of mouth and university reputation. 


\subsection{The Influence of Word of Mouth on Student Decision Selects Study}

The results showed that the positive word of mouth variable did not significantly influence the decision of the students to study. The value of regression coefficient word of mouth with $t$ test is $1.377<1.654$. At the level of $95 \%$ significance and alpha 5\%, then the hypothesis is rejected. It means that there is no significant influence of word of mouth on the decision of students to study

This study do not support Rangkuti's (2009) definition of word of mouth as a marketing business that triggers customers to discuss, promote, recommend, and sell a product, service or brand to customers. Sari and Astuti (2012) concluded that WoM had positive and significant influence on the decision of election. Also Houston et al. (2001) show that WoM could be seven times more effective than advertisement in magazine and newspaper, four times more effective from personal selling as well two times more effective than radio advertising on the business the company creates to influence customers to switch to using the previous product. According to Hasan (2010) WoM is a consumer action to provide information to other non-commercial consumers either brand, product or service. Results show that WoM has no significant effect on the decision of the students to choose the study in the faculty of economics UISU. It can be concluded that the prospective student does not consider about the information of UISU. It is supported by Kottler (2007), consumers receive and respond to word of mouth on the conditions and situations :

1. Consumers are not well informed enough to assist in making choices.

2. The product is very complex and difficult to assess by using criteria assessment.

3. Consumers are less able to assess the product, it does not matter how the information is propagated and addressed.

4. Other sources have low credibility.

5. The influence of others is more accessible than other sources and because it can be consulted by saving time and effort.

6. Strong social ties exist between the disseminator and the recipient of the information.

7. Individuals have a high need for social environment approval.

\subsection{The Influence of the University's Reputation of Student Decisions Choosing a University}

The results indicate that the reputation of the university positive and significantly influences the student's decision to choose a study at faculty economics UISU. It indicated from $t$ test result that is 8,204. It is supported by Tambunan (2010) who found that the process factors, costs, socioeconomic background, motivation, facilities, references, location, promotion, reputation, alumni, and products simultaneously influence the decision of students to choose accounting majors. Subsequently confirmed by Harahap (2004) who found that the partial reputation has an influence on student decisions to continue study in college. Andriani and Adam (2013) stated that reputation has a positive influence on students' interest in choosing accounting major in bachelor degree and also Khoiriyah et al. (2013) found that location, cost, product, socio-economic, motivation, facility, reference, promotion and reputation influence on the interest of students outside Bali to study in college. Reputation is an important factor in understanding human behavior because it has major behavioral consequences. Reputation is built with hard work, struggle, and through a long process. Reputation in question is the integrity and credibility of the college concerned. The better reputation will encourage a person's interest in choosing a college, especially in faculty of economics UISU.

This is supported by Robbins ( 2007) that reputation becomes important because it relates to a good name that will certainly affect the views or perceptions of a person. So it can be concluded that the reputation of the university is a very important determinant of the interest of prospective students in choosing universities, especially in the faculty of economics UISU. 
The result proves that the hypothesis is accepted with F-value $=123,370$. It can be concluded that word of mouth and university reputation have positive effect on the student's decision to choose to study in faculty of economics UISU. $\mathrm{R}^{2}$ is 0.586 means $58.60 \%$ independent variable (word of mouth and university reputation) explains the dependent variable (student decision.

\section{Conclusion}

Result of t test express word of mouth positively has no significant effect on student's decision to choose UISU. While the university's reputation influence positively on the student's decision to choose UISU. The $F$ test shows the word of mouth and the university's reputation simultaneously influence on the student's decision to choose a study at the economic faculty of UISU. Coefficient of determination $\mathrm{R}^{2}$ is 0.586 , which means that $58,6 \%$ student decision to choose study in UISU could be explained by WOM and university reputation.

Universitas Islam Sumatera Utara, especially the faculty of economics should continue to make more professional in fulfilling facilities and infrastructure and improving the quality of lecturers. The study program should be more creative and more tailored to meet the needs of the market so that graduates could easily find a job. Tight competition in the era of MEA requires universities to always build a good reputation through new breakthroughs that can be a mainstay and have a high selling value. UISU is required to be more professional by prioritizing user satisfaction especially students.

This research focuses on two variables, word of mouth and university's reputation as factors influencing student's decision to choose campus. The next researcher is expected to be able to add other variables such as promotion, service, security and comfort that can influence student decision to choose study in UISU.

\section{Acknowledgements}

We would like to thank the Scholarship for Doctorate program (BUDI-DN) through LPDP to fund this article, so it can be published in this journal.

\section{References}

Allam, Z. (2018). Students' perception of quality in higher education: An empirical investigation. Management Science Letters , 8(5), 437-444.

Alessandri, S. W., Yang, S.-U., \& Kinsey, D. F. (2006). An Integrative Approach to University Visual Identity and Reputation. Corporate Reputation Review, 9(4), 258-270.

Allsop, D. E. E. T., Bassett, B. R., \& Hoskins, J. A. (2007). Word-of-Mouth Research : Principles and Applications. Journal of Advertising Research(December), 398-411.

Andriani, E., \& Adam, H. (2013). Pengaruh Biaya Pendidikan, Latar Belakang Sosial Ekonomi, Motivasi dan Reputasi Terhadap Minat Mahasiswa dalam Memilih Prodi S1 Akuntansi Perguruan Tinggi di Malang. Jurnal Ilmiah Mahasiswa FEB Universitas Brawijaya. Malang, 1(2), 14-17.

Arndt, J. (1967). Role of Product-Related Conversations in the Diffusion of a New Product. Journal of Marketing Research, 4(3), 291-295.

Assauri, S. (2010). Manajemen Pemasaran. Jakarta: Rajawali Pers.

Babin, B. J., Lee, Y.-k., Kim, E.-j., \& Griffin, M. (2005). Modeling consumer satisfaction and wordof-mouth : restaurant patronage in Korea. Journal of Service Marketing, 19(3), 133-139. doi:10.1108/08876040510596803

Balmer, J. M. T., \& Greyser, S. A. (2002). Managing the Multiple Identities of the Corporation. California Management Review, 44(3), 72-86.

Balter, D., \& Butman, J. (2005). Grapevine : The New Art of Word of Mouth Marketing. New York: Portfolio Hardcover. 
Bromley, R. (2006). On and Off Campus : Colleges and Universities as Local Stakeholders. Planning, Practice \& Research, 21(1), 1-24. doi:10.1080/02697450600901400

Brown, T. J., Barry, T. E., Dacin, P. A., \& Gunst, R. F. (2005). Spreading the Word : Investigating Antecedents of Consumers ' Positive Word-of-Mouth Intentions and Behaviors in a Retailing Context. Journal of the Academy of Marketing Science, 33(2), 123-138. doi:10.1177/0092070304268417

Buttle, F. A. (1998). Word of mouth : understanding and managing referral marketing. Journal of Strategic Marketing, 6, 241-254.

Caruana, A. (2002). Service loyalty; The effects of service quality and the mediating role of customer satisfaction. European Journal of Marketing, 36(7/8), 811-828. doi:10.1108/03090560210430818

Davidow, M. (2003). Have you heard the word? The effect of Word of Mouth on Precieved Justice, Satisfaction and Repurchase Intention Following Complain Handling. Journal of Consumer Satisfaction, Dissatisfaction and Complaining Behavior, 16, 67-80.

Eberl, M., \& Schwaiger, M. (2005). Corporate reputation : disentangling the effects on financial performance. European Journal of Marketing, 39(7/8), 838-854. doi:10.1108/03090560510601798

Enterprise, J. (2010). Buzz marketing dengan google buzz dan google wave. Jakarta: PT. Media Elex Komputindo Kelompok Gramedia.

Finch, D., Hamilton, L., Baldwin, R., \& Zehner, M. (2013). An Exploratory Study of Factors Affecting Undergraduate Employability. Education + Training, 55(7), 681-704. doi:10.1108/ET-07-20120077

Fombrun, C., \& Shanley, M. (1990). What's in a Name? Reputation Building and Corporate Strategy. Academy of Management fou, 33(2), 233-258. doi:10.2307/256324

Gotsi, M., \& Wilson, A. M. (2001). Corporate reputation : seeking a definition. Corporate Communications An International Journal, 6(1), 24-30.

Gray, E. R., \& Balmer, J. M. T. (1998). Managing Corporate Image and Corporate Reputation. Long Range Planning, 31(5), 695-702.

Grunig, J. E. G., Larissa, A., Sriramesh, K., Huang, Y.-H., \& Lyra, A. (1995). Journal of Public Relations Models of Public Relations in an International Setting. Journal of Public Relations Research, 7(3), 163-186.

Harahap, D. A. (2015). Analisis Faktor-Faktor yang Mempengaruhi Keputusan Pembelian Konsumen di Pajak USU (Pajus) Medan. Jurnal Keuangan dan Bisnis, 7(3), 227-242.

Harahap, N. (2004). Analisis Faktor-Faktor yang Mempengaruhi Keputusan Mahasiswa dalam Menempuh Pendidikan Politeknik LP3I Medan. Universitas Sumatera Utara,

Hasan, A. (2010). Marketing Dari Mulut Ke Mulut (Word of Mouth Marketing). Yogyakarta: Media Press.

Hatch, M. J., \& Schultz, M. (1997). Relations between organizational culture, identity and image. European Journal of Marketing, 31(5,6), 356-365.

Heath, R. L., \& Vasquez, G. (2001). Handbook of Public Relations. Thousand Oaks California: Sage Publications.

Helm, S. (2007). One reputation or many? of corporate reputation. Corporate Communications An International Journal, 12(3), 238-254.

Houston, M. B., Walker, B. A., Hutt, M. D., \& Reingen, P. H. (2001). Cross-Unit Competition for a Market Charter : The Enduring Influence of Structure. Journal of Marketing, 65(2), 19-34.

Indrajit, R. E., \& Djokopranoto, R. (2006). Manajemen Perguruan Tinggi Modern. Yogyakarta: Andi.

Jung, N. Y., \& Seock, Y. K. (2016). The impact of corporate reputation on brand attitude and purchase intention. Fashion and Textiles, 3(20), 1-15. doi:10.1186/s40691-016-0072-y

Khoiriyah, D., Susilawati, M., \& Nilakusumawati, D. P. E. (2013). Faktor-Faktor Yang Mempengaruhi Minat Mahasiswa Asal Luar Bali Kuliah di FMIPA Universitas Udayana Bali. e-Jurnal Matematika, 2(1), 24-32.

Kotler, P. (2002). Manajemen Pemasaran (Edisi Mile ed.). Jakarta: Salemba Empat.

Kotler, P. (2005). Manajemen Pemasaran (I dan II ed.). Jakarta: Indeks. 
Kottler, P. d. K. L. K. (2007). Manajemen Pemasaran (Edisi 12 J ed.). Jakarta: PT. Indeks Kelompok Gramedia.

Melewar, T. C., Karaosmanoglu, E., \& Peterson, D. (2005). Corporate identity : Concept , components and contribution. Journal of General Management, 31(1), 59-81.

Peter, P. J., \& Olson, J. C. (1999). Consumer Behavior and Marketing Mix Strategy (5th Editio ed.). Singapore: McGraw-Hill.

Post, J., \& Griffin, J. (1997). Corporate reputation and external affairs management. Corporate Reputation Review, 1(1/2), 165-171.

Rangkuti, F. (2009). Mengukur efektivitas Program Promosi \& Analisis Kasus Menggunakan SPSS. Jakarta: Gramedia Pustaka Utama.

Robbins, S. P. (2007). Perilaku Organisasi. Jakarta: PT. Indeks Kelompok Gramedia.

Sari, R. D. K., \& Astuti, S. R. T. (2012). Analisis Pengaruh Kualitas Produk, Persepsi Harga dan Word of Mouth Communication Terhadap Keputusan Pembelian Mebel Pada CV. Mega Jaya Mebel Semarang. Diponegoro Journal of Management, 1(1), 1-13.

Schiffman, L. G., \& Kanuk, L. L. (2004). Consumer Behavior (8th Editio ed.). Upper Saddle River: Pearson Prentice Hall.

Schiffman, L. G., \& Kanuk, L. L. (2007). Perilaku Konsumen (Edisi Kedu ed.). Jakarta: PT. Indeks Kelompok Gramedia.

Sernovitz. (2009). Word of Mouth Marketing. Jakarta: Gramedia Pustaka Utama.

Smith, K. T., Smith, M., \& Wang, K. (2010). Does brand management of corporate reputation translate into higher market value ? Journal of Strategic Marketing, 18(3), 201-221.

Sontaite, M. d. B. A. (2011). Measurement Model of Corporate Reputation at Higher Education Institutions : Customers' Perspective. Systematic Research, 59, 115-130.

Sultan, P., \& Wong, H. Y. (2012). Service quality in a higher education context : an integrated model. Asia Pacific Journal of Marketing and Logistics, 24(5), 755-784.

Sumardy, Silviana, M., \& Malone, M. (2011). The Power of Word of Mouth Marketing. Jakarta: Gramedia Pustaka Utama.

Swastha, B., \& Handoko, T. H. (2008). Manajemen Pemasaran, Analisa Perilaku Konsumen (Edisi Pert ed.). Yogyakarta: BPFE.

Tambunan, L. T. (2010). Analisis Faktor-Faktor Yang Mempengaruhi Keputusan Mahasiswa Dalam Menempuh Pendidikan Pada Jurusan Akuntansi Unversitas HKBP Nomensen Medan. Universitas Sumatera Utara,

Tkalac, A., \& Ver, D. (2007). Reputation as Matching Identities and Images : Extending Davies and Chun's (2002) Research on Gaps between the Internal and External Perceptions of the Corporate Brand. Journal of Marketing Communications, 13(4), 277-290. doi:10.1080/13527260701300151

Villanueva, J., Yoo, S., \& Hanssens, D. M. (2008). The Impact of Marketing-Induced Versus Wordof-Mouth Customer Acquisition on Customer Equity Growth. Journal of Marketing Research, $X L V$ (February), 48-59.

Walker, K. (2010). A Systematic Review of the Corporate Reputation Literature: Definition, Measurement, and Theory. Corporate Reputation Review, 12(4), 357-387. doi:10.1057/crr.2009.26 www.studio.co.uk). [Corporate Reputation]. www.uisu.ac.id). [Universitas Islam Sumatera Utara].

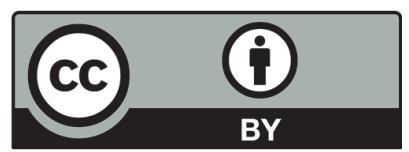

(C) 2018 by the authors; licensee Growing Science, Canada. This is an open access article distributed under the terms and conditions of the Creative Commons Attribution (CC-BY) license (http://creativecommons.org/licenses/by/4.0/). 